Editorial

\title{
New Advances on Zika Virus Research
}

\author{
Luis Martinez-Sobrido ${ }^{1, *(1)}$ and Fernando Almazán ${ }^{2}$ (D) \\ 1 Department of Microbiology and Immunology, School of Medicine and Dentistry, University of Rochester, \\ Rochester, New York, NY 14642, USA \\ 2 Department of Molecular and Cell Biology, Centro Nacional de Biotecnología (CNB-CSIC), \\ Campus Universidad Autónoma de Madrid, 3 Darwin street, 28049 Madrid, Spain; falmazan@cnb.csic.es \\ * Correspondence: Luis_Martinez@URMC.Rochester.edu
}

Received: 11 March 2019; Accepted: 11 March 2019; Published: 14 March 2019

check for updates

Zika virus (ZIKV) is an emerging mosquito-borne member of the Flaviviridae family that has historically been known to cause sporadic outbreaks, associated with a mild febrile illness, in Africa and Southeast Asia. However, the recent outbreaks of ZIKV in the Americas and its association with severe neurological disorders, including fetal microcephaly, Guillain-Barré syndrome, and ocular abnormalities, have caused a great social and sanitary alarm. The significance of ZIKV in human health, together with a lack of approved therapeutic (antivirals) or prophylactic (vaccines) interventions, has triggered a global effort to develop effective countermeasures against this pathogen, which has the potential to affect millions of people worldwide.

Since the re-emergence of the virus in 2015 in Brazil, massive advances have been made in practically all areas of the biology of ZIKV. In this Special Issue, we have assembled a collection of 32 research papers and reviews that cover recent advances on ZIKV research in molecular biology, replication and transmission, virus-host interactions, pathogenesis, epidemiology, vaccine development, antivirals, and diagnosis.

The first part of this Special Issue focuses on the development of ZIKV reverse genetic approaches, which constitute a powerful tool to answer important questions on the biology of ZIKV and for vaccine development. This theme is covered by a complete review of all ZIKV reverse genetic systems developed in the last years (Ávila-Pérez et al. [1]) and two research papers describing the generation of a ZIKV infectious clone by the mutational silencing of cryptical bacterial promoters present in the viral genome (Münster et al. [2]) and a Tet-inducible ZIKV infectious clone (Zhang et al. [3]).

The second topic of the Special Issue addresses recent advances in viral replication and transmission and is covered by three research articles (Barnard et al. [4]; Mlera and Bloom [5]; and Oliveira et al. [6]).

The third topic, virus-host interactions, includes two comprehensive reviews, one describing the molecular insights into ZIKV-host interactions (Lee et al. [7]) and other discussing the type I interferon (IFN) antagonist mechanisms used by flaviviruses, with a focus on the non-structural (NS) 5 protein (Thurmond et al. [8]). In addition, this topic includes five research manuscripts that describe the impact of viral and host genetic variations on ZIKV infection (Yun et al. [9]), the effect of ZIKV infection on Heme Oxygenase expression (Kalamouni et al. [10]), the different effects of ZIKV infection in placenta and microglia cells (Martinez-Viedma and Pickett [11]), the effect of permethrin resistance on the vector transcriptome after ZIKV infection (Zhao et al. [12]), and the microRNA and mRNA profiling in infected neurons (Azouz et al. [13]).

The fourth subject area address new advances in ZIKV pathogenesis. This theme is covered by two reviews that describe ZIKV pathogenesis in the male reproductive tract (Stassen et al. [14]) and the ocular abnormalities induced by flavivirus infection (Singh et al. [15]), and five research articles that define fetal brain infection with ZIKV isolates not associated with microcephaly (Setoh et al. [16]), the pathogenesis of Asian and African ZIKV isolates in Indian Rhesus macaques (Rayner et al. [17]), 
the consequences of ZIKV infection in human pluripotent stem cell-derived neural progenitor cells and neurons (Goodfellow et al. [18]), the effect of a single mutation in the NS2A protein in virus pathogenesis (Márquez-Jurado et al. [19]), and the roles of the premembrane (prM) and envelop (E) proteins in ZIKV-mediated infection and neurocytotoxicity (Li et al. [20]).

The fifth section in the Special Issue covers the new advances in epidemiology and virus evolution, including a manuscript describing the evolutionary insight of ZIKV strains isolated in Latin America (Simón et al. [21]).

The next section focuses on ZIKV vaccines and antivirals, and contains three review documents (Garg et al. [22]; Alves et al. [23]; Saiz et al. [24]) and two research articles that describe the antiviral effect of silvestrol (Elgner et al. [25]) and oxysterol 7-ketocholesterol (Willard et al. [26]) in ZIKV replication.

The last section in this Special Issue covers new advances in the molecular diagnostic of ZIKV, and includes a comprehensive review (Mantke et al. [27]) and five research articles that describe the development and characterization of several ZIKV diagnostic methods (Bhadra et al. [28]; de Ory et al. [29]; Zhang et al. [30]; Taylor et al. [31]; Amaro et al. [32]).

We would like to thank all contributing authors for their participation, effort and hard work in putting together this Special Issue. We would also like to thank the Editorial Office at Viruses for all the help, support, and advice with this Special Issue. We hope this Special Issue offers a comprehensive view of the recent advances in ZIKV research and stimulates research for future studies aimed at understanding ZIKV evolution, virus-host-interaction, pathogenesis, and the development of effective countermeasures to combat ZIKV infection.

Conflicts of Interest: The authors declare no conflict of interest.

\section{References}

1. Ávila-Pérez, G.; Nogales, A.; Martín, V.; Almazán, F.; Martínez-Sobrido, L. Reverse Genetic Approaches for the Generation of Recombinant Zika Virus. Viruses 2018, 10, 597. [CrossRef]

2. Münster, M.; Płaszczyca, A.; Cortese, M.; Neufeldt, C.J.; Goellner, S.; Long, G.; Bartenschlager, R. A Reverse Genetics System for Zika Virus Based on a Simple Molecular Cloning Strategy. Viruses 2018, 10, 368. [CrossRef]

3. Zhang, L.; Ji, W.; Lyu, S.; Qiao, L.; Luo, G. Tet-Inducible Production of Infectious Zika Virus from the Full-Length cDNA Clones of African- and Asian-Lineage Strains. Viruses 2018, 10, 700. [CrossRef] [PubMed]

4. Barnard, T.R.; Rajah, M.M.; Sagan, S.M. Contemporary Zika Virus Isolates Induce More dsRNA and Produce More Negative-Strand Intermediate in Human Astrocytoma Cells. Viruses 2018, 10, 728. [CrossRef] [PubMed]

5. Mlera, L.; Bloom, M.E. Differential Zika Virus Infection of Testicular Cell Lines. Viruses 2019, 11, 42. [CrossRef] [PubMed]

6. Oliveira, D.B.L.; Durigon, G.S.; Mendes, É.A.; Ladner, J.T.; Andreata-Santos, R.; Araujo, D.B.; Botosso, V.F.; Paola, N.D.; Neto, D.F.L.; Cunha, M.P.; et al. Persistence and Intra-Host Genetic Evolution of Zika Virus Infection in Symptomatic Adults: A Special View in the Male Reproductive System. Viruses 2018, 10, 615. [CrossRef] [PubMed]

7. Lee, I.; Bos, S.; Li, G.; Wang, S.; Gadea, G.; Desprès, P.; Zhao, R.Y. Probing Molecular Insights into Zika Virus-Host Interactions. Viruses 2018, 10, 233. [CrossRef]

8. Thurmond, S.; Wang, B.; Song, J.; Hai, R. Suppression of Type I Interferon Signaling by Flavivirus NS5. Viruses 2018, 10, 712. [CrossRef] [PubMed]

9. Yun, S.-I.; Song, B.-H.; Frank, J.C.; Julander, J.G.; Olsen, A.L.; Polejaeva, I.A.; Davies, C.J.; White, K.L.; Lee, Y.-M. Functional Genomics and Immunologic Tools: The Impact of Viral and Host Genetic Variations on the Outcome of Zika Virus Infection. Viruses 2018, 10, 422. [CrossRef]

10. El Kalamouni, C.; Frumence, E.; Bos, S.; Turpin, J.; Nativel, B.; Harrabi, W.; Wilkinson, D.A.; Meilhac, O.; Gadea, G.; Desprès, P.; et al. Subversion of the Heme Oxygenase-1 Antiviral Activity by Zika Virus. Viruses 2019, 11, 2. [CrossRef] 
11. Martinez Viedma, M.P.; Pickett, B.E. Characterizing the Different Effects of Zika Virus Infection in Placenta and Microglia Cells. Viruses 2018, 10, 649. [CrossRef]

12. Zhao, L.; Alto, B.W.; Shin, D.; Yu, F. The Effect of Permethrin Resistance on Aedes aegypti Transcriptome Following Ingestion of Zika Virus Infected Blood. Viruses 2018, 10, 470. [CrossRef]

13. Azouz, F.; Arora, K.; Krause, K.; Nerurkar, V.R.; Kumar, M. Integrated MicroRNA and mRNA Profiling in Zika Virus-Infected Neurons. Viruses 2019, 11, 162. [CrossRef]

14. Stassen, L.; Armitage, C.W.; Van der Heide, D.J.; Beagley, K.W.; Frentiu, F.D. Zika Virus in the Male Reproductive Tract. Viruses 2018, 10, 198. [CrossRef]

15. Singh, S.; Kumar, A. Ocular Manifestations of Emerging Flaviviruses and the Blood-Retinal Barrier. Viruses 2018, 10, 530. [CrossRef]

16. Setoh, Y.X.; Peng, N.Y.; Nakayama, E.; Amarilla, A.A.; Prow, N.A.; Suhrbier, A.; Khromykh, A.A. Fetal Brain Infection Is Not a Unique Characteristic of Brazilian Zika Viruses. Viruses 2018, 10, 541. [CrossRef]

17. Rayner, J.O.; Kalkeri, R.; Goebel, S.; Cai, Z.; Green, B.; Lin, S.; Snyder, B.; Hagelin, K.; Walters, K.B.; Koide, F. Comparative Pathogenesis of Asian and African-Lineage Zika Virus in Indian Rhesus Macaque's and Development of a Non-Human Primate Model Suitable for the Evaluation of New Drugs and Vaccines. Viruses 2018, 10, 229. [CrossRef]

18. Goodfellow, F.T.; Willard, K.A.; Wu, X.; Scoville, S.; Stice, S.L.; Brindley, M.A. Strain-Dependent Consequences of Zika Virus Infection and Differential Impact on Neural Development. Viruses 2018, 10, 550. [CrossRef]

19. Márquez-Jurado, S.; Nogales, A.; Ávila-Pérez, G.; Iborra, F.J.; Martínez-Sobrido, L.; Almazán, F. An Alanine-to-Valine Substitution in the Residue 175 of Zika Virus NS2A Protein Affects Viral RNA Synthesis and Attenuates the Virus In Vivo. Viruses 2018, 10, 547. [CrossRef]

20. Li, G.; Bos, S.; Tsetsarkin, K.A.; Pletnev, A.G.; Desprès, P.; Gadea, G.; Zhao, R.Y. The Roles of prM-E Proteins in Historical and Epidemic Zika Virus-mediated Infection and Neurocytotoxicity. Viruses 2019, 11, 157. [CrossRef]

21. Simón, D.; Fajardo, A.; Moreno, P.; Moratorio, G.; Cristina, J. An Evolutionary Insight into Zika Virus Strains Isolated in the Latin American Region. Viruses 2018, 10, 698. [CrossRef] [PubMed]

22. Garg, H.; Mehmetoglu-Gurbuz, T.; Joshi, A. Recent Advances in Zika Virus Vaccines. Viruses 2018, 10, 631. [CrossRef] [PubMed]

23. Alves, M.P.; Vielle, N.J.; Thiel, V.; Pfaender, S. Research Models and Tools for the Identification of Antivirals and Therapeutics against Zika Virus Infection. Viruses 2018, 10, 593. [CrossRef] [PubMed]

24. Saiz, J.-C.; Oya, N.J.; Blázquez, A.-B.; Escribano-Romero, E.; Martín-Acebes, M.A. Host-Directed Antivirals: A Realistic Alternative to Fight Zika Virus. Viruses 2018, 10, 453. [CrossRef] [PubMed]

25. Elgner, F.; Sabino, C.; Basic, M.; Ploen, D.; Grünweller, A.; Hildt, E. Inhibition of Zika Virus Replication by Silvestrol. Viruses 2018, 10, 149. [CrossRef]

26. Willard, K.A.; Elling, C.L.; Stice, S.L.; Brindley, M.A. The Oxysterol 7-Ketocholesterol Reduces Zika Virus Titers in Vero Cells and Human Neurons. Viruses 2019, 11, 20. [CrossRef] [PubMed]

27. Donoso Mantke, O.; McCulloch, E.; Wallace, P.S.; Yue, C.; Baylis, S.A.; Niedrig, M. External Quality Assessment (EQA) for Molecular Diagnostics of Zika Virus: Experiences from an International EQA Programme, 2016-2018. Viruses 2018, 10, 491. [CrossRef]

28. Bhadra, S.; Saldaña, M.A.; Han, H.G.; Hughes, G.L.; Ellington, A.D. Simultaneous Detection of Different Zika Virus Lineages via Molecular Computation in a Point-of-Care Assay. Viruses 2018, 10, 714. [CrossRef]

29. De Ory, F.; Sánchez-Seco, M.P.; Vázquez, A.; Montero, M.D.; Sulleiro, E.; Martínez, M.J.; Matas, L.; Merino, F.J.; Working Group for the Study of Zika Virus Infections. Comparative Evaluation of Indirect Immunofluorescence and NS-1-Based ELISA to Determine Zika Virus-Specific IgM. Viruses 2018, 10, 379. [CrossRef]

30. Zhang, L.; Du, X.; Chen, C.; Chen, Z.; Zhang, L.; Han, Q.; Xia, X.; Song, Y.; Zhang, J. Development and Characterization of Double-Antibody Sandwich ELISA for Detection of Zika Virus Infection. Viruses 2018, 10, 634. [CrossRef] 
31. Taylor, C.T.; Mackay, I.M.; McMahon, J.L.; Wheatley, S.L.; Moore, P.R.; Finger, M.J.; Hewitson, G.R.; Moore, F.A. Detection of Specific ZIKV IgM in Travelers Using a Multiplexed Flavivirus Microsphere Immunoassay. Viruses 2018, 10, 253. [CrossRef]

32. Amaro, F.; Sánchez-Seco, M.P.; Vázquez, A.; Alves, M.J.; Zé-Zé, L.; Luz, M.T.; Minguito, T.; De La Fuente, J.; De Ory, F. The Application and Interpretation of IgG Avidity and IgA ELISA Tests to Characterize Zika Virus Infections. Viruses 2019, 11, 179. [CrossRef]

2019 by the authors. Licensee MDPI, Basel, Switzerland. This article is an open access article distributed under the terms and conditions of the Creative Commons Attribution (CC BY) license (http:// creativecommons.org/licenses/by/4.0/). 